\title{
Use of sewage sludge in agricultural soils: Useful or harmful
} Sezai Delibacak a,*, Lyudmila Voronina b,c, Ekaterina Morachevskaya ${ }^{\text {b }}$ Ali Riza Onguna

\author{
a Ege University, Faculty of Agriculture, Department of Soil Science and Plant Nutrition, İzmir, Turkey \\ b Moscow State University, Faculty of Soil Science, Department of Agrochemistry and Plant Biochemistry, Moscow, \\ Russian Federation \\ ${ }^{\mathrm{c}}$ Center for Strategic Planning and Management of Biomedical Health Risks, Moscow, 119121, Russian Federation
}

\section{Article Info}

Received : 12.06 .2019

Accepted : 06.02.2020

\begin{abstract}
Sewage sludge is an important type of organic wastes among the various categories of solid waste. Organic matter resources in soils are relatively low and frequently require replenishment. Therefore, the use of sewage sludge in agricultural soils is a desirable method of their utilisation. The addition of sewage sludge to soils may be an inexpensive and effective alternative to the methods applied currently (mineral fertilisation, manure etc.). In spite of the undisputable advantages resulting from the application of sewage sludge in agriculture, it also involves some serious threats. Among those we should mention the presence of pathogens, heavy metals, and organic pollutants. In the current scenario of increasing global population, the generation of solid wastes like biosolids is bound to increase remarkably. Improper and unscientific disposal of biosolids results in several environmental issues such as surface and groundwater contamination, degradation of land, and food chain contamination. According to the principles of waste management hierarchy, agricultural recycling of biosolids will be a more environmentally preferred option over the traditional disposal methods. Utilizing the potential of biosolids to recycle valuable plant nutrients and as an effective soil amendment will not only help in sustainable management of this waste but also in minimizing the negatives associated with its traditional disposal. Every country must obey their regulations and legislations for managing their sewage sludge as a basic solution for use of sewage sludge in agricultural soil.
\end{abstract}

Keywords: Sewage sludge, biosolids, organic matter, waste management.

(C) 2020 Federation of Eurasian Soil Science Societies. All rights reserved

\section{Introduction}

Sewage sludge is an important type of organic wastes among the various categories of solid waste (Singh et al., 2014). In the present day, because of population growth, world of diminishing natural resources and energy crisis, the importance and need of developing a sustainable approach towards environmentally sound solid waste management cannot be ignored (Pappu et al., 2007). The improper disposal of solid wastes like biosolids and other biowastes pose a serious threat to the environmental quality leading to problems like groundwater contamination, degradation of soil quality, etc. Over the time, different approaches of safe biosolids disposal such as incineration, soil application, land filling (Kominko et al., 2017) and sea dumping have been explored (Sanchez Monedero et al., 2004). Disposal methods like land filling and ocean dumping have their own demerits due to scarcity of land, pollution problem and also don't lead to reuse of the beneficial constituents of biosolids (Wong, 1995; Singh and Agrawal, 2008). As a result, the United States and several European countries have banned the ocean dumping of biosolids since 1991 and 1998 (USEPA, 1999a,b; Zhidong and Wenjing, 2009).

\footnotetext{
${ }^{*}$ Corresponding author.

Ege University, Faculty of Agriculture, Department of Soil Science and Plant Nutrition, 35100 Bornova, İzmir

Tel.: +902323112653

E-mail address: sezai.delibacak@ege.edu.tr

e-ISSN: $2147-4249$

DOI: $10.18393 /$ ejss.687052
} 
Efficient municipal waste water treatment produces vast amounts of sludge. For example, in the countries located wholly or partly on the Baltic Sea watershed the amount of sewage sludge generated is about 3.5 million tonnes of dry solids annually. This is expected to increase to almost four million tonnes by 2020 . Sludge management is an integral part of any modern municipal waste water treatment plant: it is important not to lose nutrients in the sludge, to make use of its material and energy, and to dispose of it efficiently and sustainably. During recent years, much effort has been put to efficient nutrient removal from the municipal waste waters in the Baltic Sea region. The aim is to reduce the eutrophication burden to the fragile Baltic Sea by fulfilling the relevant requirements: the newer EU member states on the eastern and southern shores of the Baltic Sea have started to implement the Urban Waste Water Directive (see chapter 12 for legislation) and also to strive for the stricter HELCOM recommendations for nutrient removal (www.purebalticsea.eu). Also, in the non-EU countries of the region, actions have been taken and are still on-going to improve the level of waste water treatment. The two main sludge fractions are primary and excess secondary sludge. If phosphorus is removed from the sewage by chemical precipitation, the amount of the sludge increases by the amount of chemicals used for the precipitation. The nutrients removed from waste water are contained in the sludge, which must be handled so that the nutrients are not released back to the watercourses, while the material and energy content of the sludge can be utilised. The large amounts of sewage sludge generated in waste water treatment plants provide numerous opportunities for beneficial use; for example, in power generation, soil improvement and even nutrient recycling. The possibilities of use are dependent on the quality and amount of the sludge in question, the processes used in a particular treatment plant, and the national legislation and policies. The sludge handling strategy of an individual waste water treatment plant is shaped, for example, according to: its location, transportation costs; the quality of incoming waters; nutrient removal technology used; legal restrictions concerning sludge disposal; the availability and price of conditioning agents; and the possibilities to outsource the treated sludge products. An accurate and unbiased assessment of the risks connected to the use of sewage sludge is needed. The question is how to deal with various chemical substances present in municipal sewage sludge originating from households and how to recycle the nutrients. The issue of hazardous chemicals of the sludge is currently under debate and regulatory issues are also open with the EU Sewage Sludge Directive currently being revised (www.purebalticsea.eu). There are international political dimensions to the sludge handling issue, not only in differing legislation, energy strategies and sludge handling costs, but also because the world's mineral resources of phosphorus are depleting. The question on nutrient recycling is emerging: according to some estimates, phosphorus resources may only be sufficient for the next 50 years. These resources are located mostly in northern Africa, China and the USA. Even though there have been some optimistic estimations on the global reserves, the dependency on a single country, Morocco, is expected to grow over the century. Thus, EU food security has to rely on imported phosphorus (Schröder et al., 2011). Municipal sewage sludge contains large amounts of precious phosphorus; however, the possibilities for recycling should be taken into account already when planning sludge management alternatives. Moreover, some sewage treatment methods do not allow the phosphorus to exist in an easily usable form in the sludge (www.purebalticsea.eu).

Land application of sewage sludge has a great incentive in view of its fertilizer and soil conditioning properties, unless it contains toxic substances. The heterogeneous nature of sewage sludge produced at different treatment plants and the variations between seasons necessitates knowledge of the chemical composition of sewage sludge prior to the land application. Characteristics of sewage sludge depend on the waste water treatment processes and sludge treatment. Generally sewage sludge is composed of organic compounds, macronutrients, a wide range of micronutrients, non-essential trace metals, organic micro pollutants and microorganisms (Kulling et al., 2001).

The practical and technical challenges of sludge handling are the following:

a) stabilising sludge is not inert and can have an unpleasant odour; b) reducing the water content and sludge volume to the minimum; c) utilising the energy potential when economically possible; d) reducing the amount of harmful micro-organisms if people, animals or plants are in contact with the sludge; e) recovering phosphorus for agriculture (www.purebalticsea.eu).

The macronutrients in sewage sludge serve as a good source of plant nutrients and the organic constituents provide beneficial soil conditioning properties (Logan and Harrison, 1995).

Chemical characterization of sewage sludge collected for over 2 years from eight cities of Indiana, USA, showed that sewage sludge contained approximately $50 \%$ organic matter and $1-4 \%$ inorganic carbon. Organic $\mathrm{N}$ and inorganic $\mathrm{P}$ constituted the majority of total $\mathrm{N}$ and $\mathrm{P}$, respectively, of sludge. Organic and inorganic $\mathrm{C}$, organic $\mathrm{N}$ and inorganic $\mathrm{P}, \mathrm{Ca}$ and $\mathrm{Mg}$ were present in relatively constant concentrations in a given sludge throughout the sampling period. Inorganic $\mathrm{N}$, organic $\mathrm{P}, \mathrm{K}$ and all other metals were quite 
variable during the entire period of study The largest deviations were found for trace elements/heavy metals such as $\mathrm{Cd}, \mathrm{Zn}, \mathrm{Cu}, \mathrm{Ni}$ and $\mathrm{Pb}$ (Sommers et al., 1976).

Bradford et al. (1975) studied trace element concentrations of sludges from certain metropolitan areas of southern California to evaluate their interactions with soils to determine their effects on plant growth. The total concentrations of trace elements in sludges were highly variable depending on the sources, which were related to different industries discharging effluents in the sewerage system. Concentrations of $\mathrm{Cu}, \mathrm{Zn}, \mathrm{Ni}$, $\mathrm{Co}$ and $\mathrm{Cd}$ were consistently greater in saturation extracts obtained from sludges than those obtained from soils of any sampling sites. The maximum total concentrations of $\mathrm{B}, \mathrm{Cd}, \mathrm{Ni}, \mathrm{Cu}, \mathrm{Pb}$ and $\mathrm{Zn}$ showed positive correlations with concentrations of these elements found in soil solution.

\section{Effects of the sewage sludge application on soil properties}

\section{Physico-chemical properties}

Land application of the sewage sludge is becoming more popular due to the possibility of recycling valuable components such as organic matter, N, P and other plant nutrients (Martinez et al., 2002). Sewage sludge application to soil enables the recycling of nutrients and may eliminate the need for commercial fertilizers in cropland (Sommers, 1977). The fertility of soil increased over a long period of time, as sludges are organic fertilizers (Archie and Smith, 1981).

Unwise sludge amendment may, however, disturb the soil properties especially when it bears high concentrations of metals and toxic constituents. The soil physical conditions have been improved by sewage sludge application (Epstein, 1975, Table 2). An increase in soil pH has been reported in soils applied with municipal sewage sludge (Tsadilas et al., 1995). Lowering of soil pH is also reported (Epstein et al., 1976). The changes in soil pH have been correlated with the calcium carbonate content of sludge and acid production during sludge decomposition (Sommers, 1977). Soil $\mathrm{pH}$ consideration is especially important in view of trace metal abundance in sewage sludge. Maiti et al. (1992) characterized the sewage sludges of Calcutta, India, to assess their fertilization value. Sewage sludge $\mathrm{pH}$ was found to be neutral to slightly alkaline and to have a higher salt content in winter than in the monsoon season. The cation exchange capacity (CEC) was higher during monsoon. Exchangeable $\mathrm{Ca}^{2+}$ was the dominant cation followed by $\mathrm{Mg}^{2+}$, $\mathrm{Na}^{+}$, and $\mathrm{K}^{+}$. The sludges were rich in organic carbon and available $\mathrm{N}$.

A comparison of the data on physico-chemical characterization of selected sewage sludge from different countries collected during 1998-2002 clearly showed that pH may vary from an acidic to an alkaline range (Parkpain et al.,1998; Martinez et al., 2002; Nandakumar et al., 1998).

Organic matter added to the soil as sewage sludge composts improved the soil properties, such as bulk density, porosity and water holding capacity (Ramulu, 2002; Table 1).

Table 1. Effect of sewage sludge amendments on selected soil physical, chemical, and biological properties (Singh and Agrawal, 2008)

\begin{tabular}{|c|c|c|}
\hline Properties & Effect & References \\
\hline \multicolumn{3}{|l|}{ Physical } \\
\hline \multirow[t]{2}{*}{$\mathrm{pH}$} & Decrease & Epstein (1975), Nielson et al. (1998) \\
\hline & Increase & Tsadilas et al. (1995), Nielson et al. (1998) \\
\hline Soil aggregate stability & Increase & Ojeda et al. (2003) \\
\hline Bulk density & Decrease & Ramulu (2002), Ojeda et al. (2003) \\
\hline Water holding capacity & Increase & Epstein (1975), Ramulu (2002) \\
\hline Porosity & Increase & Ramulu (2002) \\
\hline Erosion & Decrease & Ojeda et al. (2003) \\
\hline Humus content & Increase & Kulling et al. (2001) \\
\hline \multicolumn{3}{|l|}{ Chemical } \\
\hline Toxic elements & Increase & Kulling et al. (2001), Lopez-Mosquera et al. (2000) \\
\hline Soil organic carbon & Increase & Kladivko and Nelson (1979) \\
\hline Electrical conductance & Increase & Martinez et al. (2002), Ramulu (2002) \\
\hline $\mathrm{N}$ and $\mathrm{P}$ & Increase & Martinez et al. (2002), Sommers (1977), Walter et al. (2000) \\
\hline Cation exchange capacity & Increase & Ramulu (2002), Soon (1981) \\
\hline \multicolumn{3}{|l|}{ Biological } \\
\hline Yeast population & Increase & Kulling et al. (2001) \\
\hline Pathogenic organisms & Increase & Kulling et al. (2001), Ramulu (2002) \\
\hline Aerobic bacteria & Increase & Kulling et al. (2001), Ramulu (2002) \\
\hline
\end{tabular}


A study conducted to determine the effect of $0.5 \%$ sewage sludge application to soil on water retention, hydraulic conductivity and aggregate stability showed that raw, as well as digested sludge, increased the total soil water retention capacity with the greatest increase in the raw sludge amended soil (Epstein,1975). Sludge addition in soil caused a significant increase in soil hydraulic conductivity after 27 days of incubation. Effect of sewage sludge amendments on selected soil physical, chemical, and biological properties was given on Table 1 (Singh and Agrawal, 2008).

The metal concentrations in the sewage sludge depend on several factors such as: i) sewage origin, ii) sewage treatment processes, and iii) sludge treatment processes (Hue and Ranjith, 1994). The bioavailability of the sludge borne metals to soil is further influenced by soil properties such as $\mathrm{pH}$, redox potential (Eh), sesquioxide content and organic matter, as well as sludge application rate (Hue and Ranjith, 1994; Delibacak and Ongun, 2018).

Assuming that $\mathrm{Zn}, \mathrm{Cu}$ and $\mathrm{Ni}$ behave similarly as $\mathrm{pH}$ varies, maintenance of a $\mathrm{pH}$ above 6.0 for grassland and 6.5 for arable soil to which the sewage sludge is applied, was recommended (Department of The Environment, 1981).

A study to evaluate the effect of $\mathrm{pH}$ on release of $\mathrm{Zn}, \mathrm{Cu}$ and $\mathrm{Ni}$ from the sewage sludges showed that metal concentration released to the supernatant liquid increased as $\mathrm{pH}$ decreased below the threshold value, which was 5.8 for $\mathrm{Zn}, 6.3$ for $\mathrm{Ni}$ and 4.5 for Cu loaded sludge (Adams and Sanders, 1984).

Hernandez et al. (1991) conducted a study to analyze the influence of sewage sludge application to a Calciorthid soil on the soil availability of macronutrients (N, P, and $\mathrm{K}$ ) and

heavy metals ( $\mathrm{Fe}, \mathrm{Cu}, \mathrm{Zn}, \mathrm{Mn}, \mathrm{Ni}, \mathrm{Cr}, \mathrm{Cd}$, and $\mathrm{Pb}$ ). Total $\mathrm{N}$ and extractable $\mathrm{N}$ and $\mathrm{P}$ contents increased in the sludge-amended soil, whereas the extractable $\mathrm{K}$ remained unaltered. Extractability of $\mathrm{Fe}, \mathrm{Cu}, \mathrm{Mn}, \mathrm{Zn}$ and $\mathrm{Pb}$ increased due to sludge application as compared to the control. Relatively high rates of sludge application increased the cation exchange capacity, which helped to retain essential plant nutrients within the rooting zone due to additional cation binding sites (Soon, 1981).

Such responses, however, depend upon the sewage:soil ratio. The higher organic matter proportion in sludges decreased bulk density and increased the aggregate stability (Ojeda et al., 2003; Table 2). These improvements in soil physical properties increased water-holding capacity by promoting higher water retention in sludge-amended soils (Ojeda et al., 2003; Table 1).

Korboulewsky et al. (2002) studied the effects of the sewage sludge composts applied at the rates of 10, 30, and $90 \mathrm{t} / \mathrm{ha}$ fresh wt. on a vineyard in southeastern France to quantify in situ N mineralization and soil organic matter, and to evaluate environmental risks such as $\mathrm{N}$ and $\mathrm{P}$ leaching and accumulation of heavy metals in soil. It was found that soil organic matter increased at all of the treatment doses, but neither total nor available heavy metal concentrations increased. As the sewage sludge contained very low levels of heavy metals, mainly in nonextractable and nonexchangeable forms (Breslin, 1999), composting reduced the

heavy metals availability in the raw material due to adsorption or complexing by humic substances. Mineral $\mathrm{N}$ increased in the first and in the second summers in the topsoil of amended plots. The risk of $\mathrm{N}$ leaching was very low, but $\mathrm{P}$ appeared to be the limiting factor at the recommended sludge amendment rate. Increase in $\mathrm{P}$ was significant in the top and in the subsoil of all of the treatment plots, with maximum increase at the highest rate of sludge application. At lower rates, no significant differences were observed. In soil, trace elements are distributed in various forms such as solid phases, free ions in soil solution, soluble organic mineral complexes, or adsorbed on colloidal particles. Sewage sludge addition to soils therefore could affect potential availability of heavy metals (Wang et al., 1997).

The solubility and consequently the mobility of metals added with sewage sludge are at least in part controlled by organic matter decomposition and the resultant soluble organic carriers of metals (Chaney and Ryan, 1993). Trace metal bioavailability is also dependent on the form of organic matter, i.e., soluble (fulvic acid) or insoluble (humic acid) (McBride, 1995). Insoluble organic matter inhibits the uptake of metals, which are tightly bound to organic matter and reducing the bioavailablity. Soluble organic matters, however, increase the availability by forming soluble metal organic complexes (McBride, 1995).

The high organic matter content of acid soil led to the formation of complexes with $\mathrm{Cu}$ and thus impaired its uptake by plants. A contrasting trend was found with respect to metal concentrations in acid and alkaline soils. The concentrations of $\mathrm{Zn}, \mathrm{Cu}, \mathrm{Pb}$ and $\mathrm{Ni}$ in plants decreased with increase in sludge doses for acid soil, The study further suggested that soil type has a larger effect on the metal bioavailability than sludge doses (Morera et al., 2002). 


\section{Microbial properties and soil enzymes}

Land application of biosolids often results in significant changes in the structure, diversity, or richness of plant and animal communities at a given site, due directly, and indirectly, to resulting soil improvements and changing environmental conditions (USEPA, 1994). Few studies, however, have examined the soil microbial community in ecologically based studies, particularly in semi-arid grasslands (Dennis and Fresquez 1989; Pascual et al. 1999; Barbarick et al. 2004; García-Gil et al. 2004). Such research is crucial, considering that among other functions, microbial populations control decomposition and nutrient cycling in soils (Coleman and Crossley 1996), which in turn, control aboveground dynamics (Reynolds, 2018). Furthermore, a greater understanding of biosolids long-term effects on above- and belowground dynamics will lead to a greater understanding of ecosystem-level effects. Dennis and Fresquez (1989) found that cultivable fractions of the soil microbial community from a semi-arid grassland increased linearly with the biosolids application rate (22.5, 45, and $90 \mathrm{Mg} \mathrm{ha}^{-1}$ ), and they noted that improvements in soil fertility and site restoration were reflected in diversity and composition of the soil microbial community. García-Gil et al. (2004) reported increased microbial biomass, basal respiration, metabolic quotient, and enzymatic activities in another semiarid soil, amended 9 or 36 months previously, with biosolids at approximately $36 \mathrm{Mg} \mathrm{ha}^{-1}$. Barbarick et al. (2004) examined microbial responses to biosolids in both semi-arid grassland ( 0 and $\left.30 \mathrm{Mg} \mathrm{ha}^{-1}\right)$ and shrubland ( 0 and $40 \mathrm{Mg} \mathrm{ha}^{-1}$ ) sites 6 years after biosolids surface application. At both sites, $\mathrm{CO}_{2}$ evolution and actively metabolizing microbial biomass were greater in plots 6 years following biosolids application than in control (nonamended) plots. Pascual et al. (1999) examined microbiological and biochemical parameters of semi-arid soils 8 years after biosolids amendment ( 65 and $260 \mathrm{Mg} \mathrm{ha}^{-1}$ ). Compared to control plots, the amended plots exhibited greater total organic C, microbial biomass, basal respiration rate, and enzymatic activity even 8 years after biosolids incorporation. Enzymatic activities have often been estimated to establish the indices of soil fertility. Microorganisms as well as plants synthesize enzymes, which act as a biocatalyst of important reactions to produce essential compounds for both soil microorganisms and the plants. Soil enzymatic activities can be indirectly affected by heavy metals present in the sewage sludge (Kandeler et al., 2000). The effect of sewage sludge on biological activity may be used as indicator of soil pollution (Fließbach et al., 1994). According to some researches sewage sludge amendment increased the soil microbial activity, soil respiration and soil enzymes activities (Banerjee et al., 1997; Kayikcioglu and Delibacak, 2018). However, reduction in soil enzyme activities has also been reported at longer incubation period with high heavy metal availability (Fließbach et al., 1994). Effects of adding different doses (0, 100, 200 and $300 \mathrm{t} / \mathrm{ha}$ dry wt.) and $\mathrm{C} / \mathrm{N}$ ratios (3:1, 6:1 and 9:1) of the sewage sludge on activities of bglucosidase, alkaline phosphatase, arylsulphatase and urease in a clay loam soil at $25^{\circ} \mathrm{C}$ and $60 \%$ water holding capacity were studied by Kizilkaya and Bayrakli (2005). Nitrogen was added in the form of $\left(\mathrm{NH}_{4}\right)_{2} \mathrm{SO}_{4}$ solution to the sludge to obtain different $\mathrm{C} / \mathrm{N}$ ratios. Rapid and significant increase in the soil enzymatic activity has been noted at different doses and $\mathrm{C} / \mathrm{N}$ ratios of the sewage sludge amendments as compared to unamended ones. Enzyme activities varied with differences in incubation period. Soils with the highest $\mathrm{C} / \mathrm{N}$ ratio and sludge dose had the highest b-glucosidase activity. Alkaline phosphatase and aryl sulphatase showed an increment in their activity during the first 30 days of incubation followed by a pronounced decrease compared to unamended soil. Urease activity, however, showed an increase within 15 days, and thereafter activity declined. The highest activities of urease, alkaline phosphatase and arylsulphatase were observed in soil amended with a low $\mathrm{C} / \mathrm{N}$ ratio and the highest dose of sludge (Kizilkaya and Bayrakli, 2005).

\section{Harmfull effects}

Application of sewage sludge in agriculture or for soil reclamation is an interesting solution. It is more and more frequently used in practice due to the advantageous effect of sewage sludge on the properties of soils fertilised/reclaimed with its application. Apart from soil enrichment in nutrients (Fytili and Zabaniotou, 2008), an addition of sewage sludge causes an increase in organic matter content in soil (Epstein, 2003). Organic matter resources in soils are relatively low and frequently require replenishment. Therefore, the use of sewage sludge in agriculture is a desirable method of their utilisation. The addition of sewage sludge to soils may thus be an inexpensive and effective alternative to the methods applied currently (mineral fertilisation, manure etc.). In spite of the undisputable advantages resulting from the application of sewage sludge in agriculture, it also involves some serious threats. Among those we should mention the presence of pathogens, heavy metals, and organic pollutants (Harrison et al., 2006; Oleszczuk, 2006a; Smith, 2009). Standards for maximum concentrations of pathogens in sewage sludge were given on Table 2. 
Table 2. Standards for maximum concentrations of pathogens in sewage sludge (European Commission, 2009).

\begin{tabular}{|c|c|c|}
\hline Country & Salmonella & Other pathogens \\
\hline Poland & No occurrence & Faecal streptococci: < 100/g \\
\hline France & $8 \mathrm{MPN} / 10 \mathrm{~g} \mathrm{DM}$ & $\begin{array}{l}\text { Enterovirus: } 3 \text { MPCN/10g of DM } \\
\text { Helminths eggs: } 3 / 10 \mathrm{~g} \text { of DM }\end{array}$ \\
\hline Finland & Not detected in $25 \mathrm{~g}$ & Escherichia coli $<1000 \mathrm{cfu}$ \\
\hline Italy & $1000 \mathrm{MPN} / \mathrm{g} \mathrm{DM}$ & - \\
\hline Luxembourg & - & $\begin{array}{l}\text { Enterobacteria: } 100 / g \text { no eggs of worm likely to be } \\
\text { contagious }\end{array}$ \\
\hline Hungary & s & $\begin{array}{l}\text { Faecal coli and faecal streptococci decrease below } 10 \% \text { of } \\
\text { original number }\end{array}$ \\
\hline Poland & $\begin{array}{l}\text { Sludge cannot be used in } \\
\text { agriculture if contains salmonella }\end{array}$ & - \\
\hline
\end{tabular}

Proposed limit values on potentially toxic elements (PTE) in sewage sludge and in soil were presented in Table 3.

Table 3. Proposed limit values on potentially toxic elements (PTE) in sewage sludge and in soil (mg kg-1 $\mathrm{dw}$ ) (European Commission, 2009).

\begin{tabular}{llccc}
\hline \multirow{2}{*}{ Metal } & \multirow{2}{*}{ Sludge } & \multicolumn{2}{c}{ Soil } \\
\cline { 3 - 5 } & & $5<\mathrm{pH}<6$ & $6<\mathrm{pH}<7$ & $\mathrm{pH}>7$ \\
\hline $\mathrm{Cd}$ & 10 & 0.5 & 1 & 1.5 \\
$\mathrm{Cr}$ & 1000 & 50 & 75 & 100 \\
$\mathrm{Cu}$ & 1000 & 30 & 50 & 100 \\
$\mathrm{Hg}$ & 10 & 0.1 & 0.5 & 1 \\
$\mathrm{Ni}$ & 300 & 30 & 50 & 70 \\
$\mathrm{~Pb}$ & 750 & 70 & 70 & 100 \\
$\mathrm{Zn}$ & 2500 & 100 & 150 & 200 \\
\hline
\end{tabular}

The treatment of sewage sludge for agricultural purposes in Russia is regulated by two main documents, which allow to exclude to a certain extent the negative impact on the environment and human health. These are State All-Union Regulations R 17.4.3.07-2001 "Requirements for the composition and properties of sewage sludge when used as fertilizers" (Table 4), focusing on agrochemical and soil indicators, and Sanitary and epidemiological rules 2.1.7.573-96 "Hygienic requirements for the use of wastewater and its precipitation for irrigation and fertilizer" (Table 5), which determines the requirements for the quality of precipitation from a hygienic point of view.

Table 4. Permissible total content of heavy metals and arsenic in sewage sludge

\begin{tabular}{|c|c|c|}
\hline \multirow{2}{*}{ Metals } & \multicolumn{2}{|c|}{ Concentration, $\mathrm{mg} \mathrm{kg}^{-1}$ dry matter } \\
\hline & 1 & 2 \\
\hline $\mathrm{Pb}$ & 250 & 500 \\
\hline $\mathrm{Cd}$ & 15 & 30 \\
\hline $\mathrm{Ni}$ & 200 & 400 \\
\hline $\mathrm{Cr}$ & 500 & 1000 \\
\hline $\mathrm{Zn}$ & 1750 & 3500 \\
\hline $\mathrm{Cu}$ & 750 & 1500 \\
\hline $\mathrm{Hg}$ & 7,5 & 15 \\
\hline As & 10 & 20 \\
\hline
\end{tabular}

Table 5. Sanitary-bacteriological and sanitary-parasitological indicators of sewage sludge

\begin{tabular}{lcc}
\hline \multirow{2}{*}{ Indicator } & \multicolumn{2}{c}{ Standard } \\
\cline { 2 - 3 } & $1^{*}$ & $2^{* *}$ \\
\hline E.coli group bacteria, cells g-1 actual moisture & 100 & 1000 \\
Pathogenic microorganisms, including Salmonella, cells g-1 & - & - \\
Geohelminth eggs and cysts of intestinal pathogenic protozoa, sample kg-1 & - & - \\
\hline
\end{tabular}

Geohelminth eggs and cysts of intestinal pathogenic protozoa, sample $\mathrm{kg}^{-1}$

1,2 - groups of sewage sludge

*Sewage sludge of group 1 is used for all kinds of crops, except vegetables, mushrooms, green and strawberries.

** Sewage sludge of group 2 is used for leguminous, cereals and industrial crops.

Sewage sludge of both groups is used in industrial floriculture, green building, forest and ornamental nurseries, for biological reclamation of disturbed lands and landfills. 
Very rarely do urban sewerage systems transport only domestic sewage to the treatment plants. Industrial effluents and storm-water run off from roads and other paved areas are frequently discharged into the sewerage system. Thus sewage sludge may also contain many toxics in addition to organic material. Sewage sludge may also contain other harmful toxics such as detergents, various salts and pesticides due to effluents from municipal, industrial premises, toxic organics and harmone disruptors (Sommers et al., 1976). Organic pollutants are particularly important, due to its diversity. That diversity is related both with the method of toxic effect, and with diversified effects on living organisms (mutagenic effect, carcinogenic effect, endocrine disrupting effect) (Singh and Agrawal, 2008). With the development of analytical techniques, more and more often new potentially toxic organic compounds are identified in sewage sludge (Müller et al., 2006; Clarke and Smith, 2011; Davis et al., 2012).

Due to the multitude of those substances, and to the fact that their identification requires professional equipments, such contaminants are usually not the subject of routine chemical analyses. The lack of accurate information in this respect increases the risk involved in the application of sewage sludge. In this situation, biological tests may be helpful in the identification of potential threats. Biological tests permit not only measurable determination of a threat (toxic effect) but also take into account the possible interactions among the particular contaminants (antagonism/synergy effect). Moreover, the use of biological tests permits estimation of threats related with the presence of so far unidentified contaminants with potentially toxic effect. In this aspect, the estimation of phytotoxicity of sewage sludge is of particular importance due to its frequent utilisation for natural purposes. Moreover, plants are essential primary producers in the terrestrial ecosystem, whereas crop yield and quality are important success criteria in agriculture.

The application of phytotoxicity tests, therefore, permits not only to evaluate the applicability of sewage sludge for agricultural or soil reclamation purposes, but also to identify potential threats for the environment and for human health. Most of the studies concerned with the estimation of phytotoxicity of sewage sludge have been focused on the estimation of toxicity of the sewage sludge as such (Ramírez et al., 2008a;b; Hu and Yuan, 2012). Those studies, however, do not take into account other significant parameters, important in the assessment of the natural utilisation of sewage sludge. The toxicity of sewage sludge can also be significantly affected by the type of soil in which it is introduced (Domene et al., 2010), as well as by the kind of matrix under estimation (water extract or solid phase) (Domene et al., 2008). On the basis of studies conducted so far (Suchkova et al., 2010), it is also to be supposed that the species of plants grown can have a significant effect of the phytotoxicity of soil amended with sewage sludge, especially in the long-term approach. In spite of the importance of those problems, however, the literature lacks a comprehensive approach to those issues.

Oleszczuk et al. (2012) stated that their study aim was the estimation of changes in the phytotoxicity of soils amended with sewage sludge with relation to Lepidium sativum, Sinapis alba and Sorghum saccharatum. The study was realised in the system of a plot experiment for a period of 29 months. Samples for analyses were taken at the beginning of the experiment, and then after 5, 17 and 29 months. Two kinds of sewage sludge, with varying properties, were added to a sandy soil or a loamy soil at the dose of $90 \mathrm{t} / \mathrm{ha}$. The addition of sewage sludge to the soils at the start of the experiment caused a significant reduction of both seed germination capacity and root length of the test plants, the toxic effect being distinctly related to the test plant species. With the passage of time the negative effect of sewage sludge weakened, the extent of its reduction depending both of the kind of sewage sludge applied and on the type of soil. Phytotoxicity of the soils amended with the sewage sludges was significantly lower at the end of the experiment than at the beginning. The species of the plants grown on the soils also had a significant effect on their phytotoxicity. The greatest reduction of toxicity was observed in the soil on which no plants were grown (sandy soil) and in the soil under a culture of willow (loamy soil). Solid phase of sewage sludge-amended soils was characterised by higher toxicity than their extracts. Most likely the reason of phytotoxicity was high doses of sewage sludge application.

A number of studies concerning the fate of organic and inorganic pollutants in soils amended with sewage sludge indicate that those compounds undergo a variety of processes (e.g. adsorption, desorption, bioformation, volatilisation, photodegradation, bioaccumulation, leaching and incorporation into humic substances structures -sequestration or bound residue formation-) (Hesselsøe et al., 2001; La Guardia et al., 2001; De Jonge et al., 2002). Those processes significantly determine the bioavailability of the pollutants (Alexander, 2000) and, indirectly, also their toxicity. In a study, after 29 months, in almost all treatments a significant decrease of phytotoxicity was observed in soils amended with sewage sludge in relation to the beginning of the experiment. Most probably that was a result of combination of all of the processes mentioned above. Moreover decreasing of the toxicity of the sewage sludge amended soil could be related 
with quickly degraded labile compounds which very often occurs in sewage sludges and act as phytotoxins. The increase of phytotoxicity observed after 5 months in most of the experimental treatments was most probably related with remobilisation of pollutants, fairly frequently observed in soils amended with sewage sludge or composts (Oleszczuk, 2006b). Terry et al. (1979) and Rowell et al. (2001) stated that 26-42\% of the organic matter introduced together with the sludge underwent mineralisation very quickly. As a result of that process, formerly unavailable pollutants related with organic matter undergo remobilisation. An increase in the phytotoxicity after 5 months wasmost probably related to the fact that the organic contaminants, initially adsorbed to the sewage sludges/soil mixture, were temporarily less available. As a result of organic matter mineralization, the strength of these bonds could weaken, and hence, there was an increase in the bioavailability of pollutants which had not been bioavailable earlier (Oleszczuk, 2006b).

It is commonly accepted that toxicity largely depends on the water solubility of pollutants. However, studies on the sewage sludge phytotoxicity concentrate mainly on the analysis of water extracts (Wong et al., 2001; Fuentes et al., 2006; Mantis et al., 2005). The application of water extracts provides important information; however, they do not give a fully comprehensive description of the toxicity of sewage sludges. The results obtained in a study showed clearly that the analysis of extracts is not sufficient for the full characterisation of risks related with sewage sludge. This is also supported by earlier studies conducted with relation of other organisms and environmental matrices (Chial and Persoone, 2003; Ramírez et al., 2008a).

\section{Organic pollutants}

Sewage sludges can contain significant concentrations of toxic heavy metals and organic pollutants (Guo et al., 2009). The sources of these pollutants in the waste waters are discharges from domestic and industrial facilities and atmospheric deposition as well as urban runoff (Blanchard et al., 2001; Harrison et al., 2006; Guo et al., 2009). Hence, these kinds of pollutants are concentrated in the sewage sludge during waste water treatment. This issue is of great risk to human health because transfer pathways of these pollutants into the human food-chain might be food crops or grazing livestock which eat contaminated feed grown on sludgeamended soil (McLachlan et al., 1996). Among these organic pollutants, polycyclic aromatic hydrocarbons (PAHs) are ubiquitous environmental contaminants that originate from different emission sources, like the incomplete combustion of fossil fuels, industrial processes or the use of motor vehicles (Ozcan et al., 2013).

According to the data of Russian studies of the urban sewage sludge of Moscow, there are more than 200 polluting organic substances of anthropogenic nature, belonging to different groups of chemical compounds: acyclic saturated hydrocarbon, unsaturated hydrocarbons, aromatic cyclic hydrocarbons, polycyclic aromatic hydrocarbons, oxygen-containing compounds. Among them, $1.16 \%$ by weight belonged to toxic aromatic hydrocarbons, of which toluene was found in concentrations on average up to 10 times higher than MPC (maximum permitted concentrations) for soil. Also found naphthalene, methylnaphthalene, fluorene, phenanthrene, anthracene, pyrene and fluoranthene, belonging to the highly toxic group of polycyclic aromatic hydrocarbons (Kasatikov et al., 2017).

Concerning organics, the following are considered of primary importance for EU as limits are to be set in the revision of Sewage Sludge Directive: AOX (sum of halogenated organic compounds) linear alkylbenzene sulphonates (LAS) di(2-ethylhexyl)phthalate (DEHP) NPE (nonylphenole and nonylphenole ethoxylates with 1 or 2 ethoxy groups) polycyclic aromatic hydrocarbons (PAHs) polychlorinated biphenyls (PCBs) polychlorinated dibenzo-p-dioxins and -furans (PCDD/Fs). Limit values for concentrations of organic compounds in sludge of different countries and as suggested in the 3rd draft of the Working paper on sludge for EU (Langenkamp et al., 2001) were presented on Table 4.

Table 4. Limit values for concentrations ( $\mathrm{mg} \mathrm{kg}^{-1} \mathrm{dw}$ ) of organic compounds in sludge of different countries and as suggested in the 3rd draft of the "Working paper on sludge" for EU (Langenkamp et al., 2001).

\begin{tabular}{llllllll}
\hline & AOX & DEHP & LAS & NP/NPE & PAH & PCB & PCDD/F, ng TEq/kg dm \\
\hline EU & 500 & 100 & 2600 & 50 & 6 & $0.8^{2}$ & 100 \\
Denmark & - & 50 & 1300 & 10 & $3^{1}$ & - & - \\
Sweden & - & - & - & 50 & $3^{3}$ & $0.4^{4}$ & - \\
Lower Austria & 500 & - & - & - & - & $0.2^{5}$ & 100 \\
Germany & 500 & - & - & - & - & $0.2^{5}$ & 100 \\
\hline
\end{tabular}

${ }^{1}$ Sum of acenapthene, phenanthrene, fluorine, fluoranthene, pyrene, benzo $(b+j+k)$ fluoranthne, benzo(a)pyrene, benzo(ghi)perylene, indeno(1,2,3-c,d)pyrene

${ }^{2}$ Sum of 6 congeners PCB 28, 52, 101, 138, 153, 180

${ }^{3}$ Sum of 6 compounds

${ }^{4}$ Sum of 7 congeners

${ }^{5}$ Each of the six congeners PCB 28, 52, 101, 138, 153, 180. 


\section{Polycyclic aromatic hydrocarbons (PAHs) contents and sources}

Polycyclic aromatic hydrocarbons are one of the most important groups of ecotoxicants due to their high toxicity, considerable stability in the environment, a cumulative effect. They are chemically inert and are hardly affected by the action of acids and oxidizing agents. Certain members of the PAH class have been listed as priority pollutants by Environmental Protection Agencies of the United States, Europe and China. The PAHs often detected in sewage sludge are mainly naphthalene, phenanthrene, anthracene, fluorene, acenaphthene, acenaphthylene, 1,2benzanthracene, benzo(a)pyrene, benzo(b) fluoranthene, benzo(g,h,i)perylene, benzo(k) fluoranthene, fluoranthene, indeno(1,2,3-cd)pyrene and pyrene (Zhai et al., 2011).

The origin of PAHs in sewage can be from combustion of petroleum, kerosene, grass, coal, and wood. Concentration ratios of some PAHs are often used to estimate the sources of PAHs, i.e., combustion and petroleum sources (Soclo et al., 2000). Using molecular mass of 178 as an indicator, anthracene to(anthraceneșphenanthrene) ratio with $<0.10$ usually represents the petroleum sources PAHs, while the ratio with $>0.10$ is often considered as an indication of combustion sources (Budzinski, 1997). Yunker et al. (2002) reported that the ratio of (benz[a]anthracene)/(benz[a]anthraceneschrysene) lower than 0.20 implies a petroleum source; the ratio from 0.20 to 0.35 means either petroleum or combustion sources; and the ratio higher than 0.35 indicates combustion sources.

The study of samples collected at a waste-water treatment plant in Shanghai (China) indicates that PAHs release regularly according to temperature changes in the process of sewage sludge incineration treatment (Zhang et al., 2016). Over $90 \%$ of total PAHs in sewage sludge are released at the temperature of $300-750^{\circ} \mathrm{C}$. The transformation of naphthalene to indeno $(1,2,3 \mathrm{~cd})$ pyrene may be related to the temperature of the treatment system. It has been shown that the output rate of transformation reactions for indeno $(1,2,3-\mathrm{cd})$ pyrene is $94 \%$ at $300^{\circ} \mathrm{C}$.

The source of wastewater, wastewater treatment methods and different treatment process affect the PAH concentrations in sludge. The PAHs concentrations varied strongly between the sludges from primary and secondary treatment processes: the sum of PAHs in the primary sludge were 1.5973 and $0.3402 \mathrm{mg} / \mathrm{kg}$, in the secondary sludge they were 8.7884 and $2.0185 \mathrm{mg} / \mathrm{kg}$ respectively (Zhai et al., 2011). An enrichment of PAHs over time can be explained by the longer retention time of secondary sludge in comparison with primary sludge.

Previous studies reported a large range in the total concentration of PAHs in sewage sludge from Asian, African, and European countries, varying from below detection to 33,000 ng/g dry weight (Cai et al. 2007; Man et al. 2016; Poluszyńska et al. 2017).

According to Turkish regulation, concentration of total PAHs (naphthalene, acenaphthylene, acenapthene, fluorene, phenanthrene, anthracene, fluoranthene, pyrene, benzo[a]anthracene, chrysene, benzo[b]fluoranthene, benzo[k]fluoranthene, benzo[a]pyrene Indeno[1,2,3-c,d]pyrene, dibenzo[a,h]anthracene, benzo[g,h,i]perylene, benzo[j]fluoranthene) should be $<6 \mathrm{mg}^{\mathrm{kg}^{-1}}$ dry matter. According to EU regulation, concentration of total PAHs (acenapthene, phenanthrene, fluorene, plouranthene, pyrene, benzo[b;j;k]fluoranthene, benzo[a]pyrene, benzo[g,h,i]perylene, indeno[1,2,3c,d]pyrene) should be $<6 \mathrm{mg} \mathrm{kg}^{-1}$ dry matter. If the ratio is $>0.50$, the combustion of kerosene, grass, coal, and wood results in the PAH contamination. If fluoranthene/(fluoranthenespyrene) ratio for sludge was $<0.50$, which means the origin of PAHs was petroleum combustion. While this ratio for sludge was $>0.50$, indicating possible source of PAHs was combustion of kerosene, grass, coal, and wood (Ozcan et al., 2013).

Russian legislation in the field of health and environmental protection provides the standards only for the content of benzo (a) pyrene -0,02 $\mathrm{mg} \mathrm{kg}^{-1}$ (SanPiN GN 2.1.7.2041-06).

\section{Polychlorinated biphenyls (PCBs) contents}

Although sewage sludge improves soil properties, numerous studies have demonstrated that they also contain toxic organic compounds, such as polychlorinated biphenyls (PCBs) (McLachlan et al. 1996; Urbaniak et al. 2014; Wyrwicka et al. 2014), PCBs are found in the natural environment because of human activities (Borja et al., 2011). Approximately 30\% (i.e., 10 million tonnes) of the total worldwide production of PCBs has entered the environment (Benabdallah El-Hadj et al., 2007). The presence of these compounds in sewage sludge significantly decreases the potential for the sludge to be used in agriculture. According to proposed changes to EU Directive 1986/278/EEC, the polychlorinated biphenyl (PCB) concentration (expressed as the sum of the concentrations of the indicator congeners, PCBs 28, 52,101, 118, 138, 153, and 180 ) should not exceed $0.8 \mathrm{mg} / \mathrm{kg}$ dry matter (DM) in sewage sludge used as a crop fertilizer. Many researches confirm the presence of PCBs in sewage sludge and organic waste, which should be utilized (Blanchard et al., 2004). Two biological methods are generally used: composting and the anaerobic 
digestion. Rosinska and Dabrowska obtained decrease of PCB content over 50\% during anaerobic digestion of sludge (Rosińska and Dabrowska, 2014). Despite the fact that PCBs show a strong affinity to organic matter which predispose them to be stored in the sediments (Gdaniec-Pietryka et al., 2013) and surface layer of the soil, it has been also shown that they can be transferred deeper into the soil profile (Bi et al., 2002; Kobasić et al., 2008; Zhang et al., 2011). Hence, the continued use of such contaminated sludge for agricultural purposes can present problems associated with the risk of soil, subsurface and groundwater contamination (Bi et al., 2002). This also concerns nutrients, which despite being valuable from the perspective of agriculture, their combined application with sewage sludge may lead to health and environmental risks associated with subsurface and groundwater pollution (Kang et al., 2011).

The Turkish and EU regulations describes that levels of PCBs (sum of PCB 28, 52, 101, 118, 138, 153, and 180 ) in sewage sludges should be $<0.8 \mathrm{mg} \mathrm{kg}^{-1}$ (dry weight) in order to be used in agriculture (Ozcan et al., 2013). Ozcan et al. (2013) indicated that the PCB concentrations of all investigated sewage sludges in their study were less than the limit value, it was found that use of them for agricultural purposes was suitable.

\section{Conclusions}

Sewage sludge to be utilised in agriculture must be subjected to comprehensive evaluation comprising not only the determination of the basic physicochemical properties, content of pollutants or pathogenic bacteria, but also of the ecotoxicological properties. i) phytotoxicity of sewage sludge and its changes overtime are significantly determined by the soil type. In this case, the soil type is one of the most important factors regulating the phytotoxicity of sewage sludge, especially in the long-term aspect; ii) with the passage of time the phytotoxicity of soils amended with sewage sludge undergoes a change, not always in a direction causing a lowering of their toxicity. The extent of particular changes depends both on the properties of the soils and on the kind of sewage sludge, and for various kinds of sludge, it can have different direction in a single soil; iii) the extent of changes in the toxic effect on the test plants is related to the species of the plant under cultivation; iv) in spite of similar initial toxicity displayed by various kinds of sewage sludge in relation to particular plants, further changes of phytotoxicity may vary with relation to the sewage sludge and the type of soil; v) the intensity of toxicity towards various plants depends not only on the kind of sewage sludge but also on the soil type; vi) proper selection of the conditions of management sludge-amended soil can be conducive to a reduction of phytotoxicity; and vii) estimation of extracts is not sufficient for the full characterisation of the risk involved in the utilisation of sewage sludge in agriculture.

On the other hand, biosolids is a good source organic matter as well as plant macro and micro-nutrients and in future can be substituted for expensive inorganic fertilization. Addition of treated biosolids to soil has been found to be beneficial to soil health, enriching soil with essential nutrient elements as also increasing the $\mathrm{pH}$ of the soil. Further, soil amendments with biosolids has been reportedly effective in increasing a number of agro morphological attributes as well as yield in different crop species. However, use of biosolids for commercial agriculture has to be done cautiously. It is common knowledge that biosolids often contains toxic metal residues (heavy metals), as well as toxic organic residues, indiscriminate use of it can be detrimental to the productivity of the soil as well as cause harm to the food chain. Moreover the character of the biosolids changes over time and hence stringent and periodic monitoring of biosolids for agricultural use should be done. In general, a potential waste management depends on several tiers like disposal, recovery, recycle, reuse and prevention. This hierarchy is also suitable for managing biosolids. It is evident that implication of biosolids induce agricultural productivity to a certain level; but the application of this waste in major food generation and supply chain is still needs more study.

International as well as national guidelines on the carrying capacity of toxicants in biosolids composts should be set and stringent monitoring of such guidelines should be enforced in agricultural use of biosolids. Attempts for commercial production of biosolids based fertilizer and soil health amendments can be setup and can be used to boost agricultural production, and minimizing the dependency on inorganic fertilization. This will further reduce the carbon footprint, as most inorganic fertilizers are manufactured at high energy costs. Biosolids can be used for regaining soil fertility in agricultural lands deemed infertile by prolonged and indiscriminate use of synthetic inorganic fertilizers. In such conditions, depletion of soil nutrients as well as decreased soil $\mathrm{pH}$ can be rejuvenated with the rational use of biosolids. Owing to high nutrient efficiency and its importance in agriculture and soil fertility, stringent and persistent monitoring of biosolids and its products should be done before introduction in agricultural systems.

In the current scenario of increasing global population, the generation of solid wastes like biosolids is bound to increase remarkably. Improper and unscientific disposal of biosolids results in several environmental issues such as surface and groundwater contamination, degradation of land, and food chain contamination. 
Hence, according to the principles of waste management hierarchy, agricultural recycling of biosolids will be a more environmentally preferred option over the traditional disposal methods. Utilizing the potential of biosolids to recycle valuable plant nutrients and as an effective soil amendment will not only help in sustainable management of this waste but also in minimizing the negatives associated with its traditional disposal. Every country must obey their regulations and legislations for managing their sewage sludge.

Researchers around the world are looking for the most optimal set of substances for priority analysis. The knowledge of which will be used to find the best path to deal with the problem of rational and, necessarily, environmentally-safe way of disposal of sewage sludge. Perhaps more fundamental research using new modern chemical methods for the analysis of hazardous organic compounds can tighten the control on the qualitative composition of sewage sludge used in agriculture.

\section{References}

Adams, T.McM., Sanders, J.R., 1984. The effect of pH on the release to solution of zinc, copper and nickel from metal loaded sewage sludges. Environmental Pollution Series B, Chemical and Physical 8(2): 85-99.

Alexander, M., 2000. Aging, bioavailability, and overestimation of risk from environmental pollutants. Environmental Science and Technology 34: 4259-4265.

Archie, S.G., Smith, M., 1981. Survival and growth of plantations in sewage sludge treated soil and older forest growth study. In: Municipal Sludge Application to Pacific North-West forest lands. Bledose, C.B. (Ed.), University of Washington, College of Forest Resources, Washington, DC, USA. pp. 105-113.

Banerjee, M.R., Burtonand, D.L., Depoe, S., 1997. Impact of sewage sludge application on soil application characteristics. Agriculture, Ecosystems \& Environment 66(3:, 241-249.

Barbarick. K., Doxtader, K.G., Redente, E.F., Brobst, R.B., 2004. Biosolids effects on microbial activity in scrubland and grassland soil. Soil Science 169(3):176-187.

Benabdallah El-Hadj, T., Dosta, J., Torres, R., Mata-Alvarez, J., 2007. PCB and AOX removal in mesophilic and termophilic sewage sludge digestion. Biochemical Engineering Journal 36(3): 281-287.

Bi, X., Chu, S., Meng, Q., Xu, X., 2002. Movemnt and retention of polychlorinated biphenyls in a paddy field of WenTai are in China. Agriculture, Ecosystems \& Environment 89(3): 241-252.

Blanchard, M., Teil, M.J., Ollivon, D., Garban, B., Chestérikoff, C., Chevreuil, M., 2001. Origin and distribution of polyaromatic hydrocarbons and polychlorobiphenyls in the urban effluents to waste water treatment plants of the Paris Area (FRANCE), Water Research 35(15): 3679-3687.

Blanchard, M., Teil, M.J., Ollivon, D., Legenti, L. Chevreueil, M., 2004. Polycyclic Aromatic hydrocarbons and polychlorobiphenyls in waste waters and sewage sludges from the Paris Area (France). Environmental Research 95(2): 184-197.

Borja, Á., Belzunce, M. J., Garmendia, J. M., Rodríguez, J. G., Solaun, O., Zorita, I., 2011. Impact of pollutants on coastal and benthic marine communities. In: Ecological Impacts of Toxic Chemicals. Sánchez-Bayo, F., van den Brink, P. J., Mann, R.M. (Eds.). Bentham Science Publishers Ltd. pp. 165-186

Bradford, G.R., Page, A.L., Lund, L.J., Olmstead, W., 1975. Trace element concentrations of sewage treatment plant effluents and sludges; their interactions with soils and uptake by plants. Journal of Environmental Quality 4(1): 123-127.

Breslin, V.T., 1999. Retention of metals in agricultural soils after amending with MSW and MSW-biosolids compost. Water, Air, and Soil Pollution 109(1-4): 163-178.

Budzinski, H., Jones, I., Bellocq, J., Pierard, C., Garrigues, P., 1997. Evaluation of Sediment Contamination by Polycyclic Aromatic Hydrocarbons in the Gironde Estuary. Marine Chemistry 58(1-2): 85-97.

Chaney, R.L., Ryan, J.A., 1993. Heavy Metals and Toxic Organic Pollutants in MSW-Compost: Research Results on Phytoavailability, Bioavailability, Fate, etc. In: Science and Engineering of Composting Design, Environmental, Microbiological and Utilization Aspects. Hoitink, H.A.J., Keener, H.M. (Eds.). Renaissance Publications, Worthington, pp.451-506.

Chial, B., Persoone, G., 2003. Cyst-based toxicity tests XV application of ostracod solid-phase microbiotest for toxicity monitoring of contaminated soils. Environmental Toxicology 18(5): 347-352.

Clarke, B.O., Smith, S.R., 2011. Review of 'emerging' organic contaminants in biosolids and assessment of international research priorities for the agricultural use of biosolids. Environmental International 37(1): 226-247.

Coleman, D.C., Crossley, D.A.Jr., 1996. Fundamentals of Soil Ecology. Academic Press, San Diago USA. 375p.

Davis, E.F., Klosterhaus, S.L., Stapleton, H.M., 2012. Measurement of flame retardants and triclosan in municipal sewage sludge and biosolids. Environmental International 40: 1-7

De Jonge, H., De Jonge, L.W., Blicher, B.W., Moldrup, P., 2002. Transport of Di(2-ethylhexyl)phthalate (DEHP) applied with sewage sludge to undisturbed and repacked soil columns. Journal of Environmental Quality 31(6): 19631971.

Delibacak, S., Ongun, A.R., 2018. Influence of treated sewage sludge applications on total and available heavy metal concentration of sandy clay soil. Desalination and Water Treatment 112: 112-118.

Dennis, G.L., Fresquez, P.R., 1989. The soil microbial community in a sewage sludge amended grassland. Biology and Fertility of Soils 7(4): 310-317. 
Department of the Environment, 1981. Report of the sub-committee on the disposal of sewage sludge to land. Department of Environment and National Water Council, London.

Domene, X., Alcañiz, J.M., Andres, P., 2008. Comparison of solid-phase and eluate assays to gauge the ecotoxicological risk of organic wastes on soil organisms. Environmental Pollution 151(3): 549-558.

Domene, X., Colón, J., Uras, M.V., Izquierdo, R., Àvila, A., Alcañiz, J.M., 2010. Role of soil properties in sewage sludge toxicity to soil collembolans. Soil Biology and Biochemistry 42(11): 1982-1990.

Epstein, E., 1975. Effect of sewage sludge on some soil physical properties. Journal of Environmental Quality 4(1): 139142.

Epstein, E., 2003. Land application of sewage sludge and biosolids. CRC Press, Boca Raton, USA. 216p.

Epstein, E., Taylor, J.M., Chaney, R.L., 1976. Effects of sewage sludge and sludge compost applied to soil on some soil physical and chemical properties. Journal of Environmental Quality 5(4): 422-426.

European Commission, 2009. Environmental, economic and social impacts of the use of sewage sludge on land. Consultation Report on Options and Impacts, Report by RPA, Milieu Ltd and WRc for the European Commission, DG Environment under Study Contract DG ENV.G.4/ETU/2008/0076r.

Fließbach, A., Martens, R., Reber, H.H., 1994. Soil microbial biomass and microbial activity in soils treated with heavy metal contaminated sewage sludge. Soil Biology and Biochemistry 26(9): 1201-1205.

Fuentes, A., Llorens, M., Sacz, J., Aguilar, M.I., Perez-Marin, A.B., Ortuno, J.F., Meseguer, V.F., 2006. Ecotoxicity, phytotoxicity and extractability of heavy metals from different stabilized sewage sludges. Environmental Pollution 143(2): 355-360.

Fytili, D., Zabaniotou, A., 2008. Utilization of sewage sludge in EU application of old and new methods-a review. Renewable and Sustainable Energy Reviews 12(1): 116-140.

García -Gil, J. C., Plaza, C., Senesi, N., Brunetti, G., Polo, A., 2004. Effects of sewage sludge amendment on humic acids and microbiological properties of a semiarid Mediterranean soil. Biology and Fertility of Soils 39(5): 320-328.

Gdaniec-Pietryka, M., Mechlińska, A., Wolska, L. Gałuszka, A., Namieśnik, J., 2013. Remobilization of polychlorinated biphenyls from sediment and its consequences for their transport in river waters. Environmental Monitoring and Assessment 185: 4449-4459.

Guo, L., Zhang, B., Xiao, K., Zhang, Q., Zheng, M., 2009. Levels and distributions of polychlorinated biphenyls in sewage sludge of urban waste water treatment plants. Journal of Environmental Sciences 21(4): 468-473.

Harrison, E.Z., Oakes, S.R., Hysell, M., Hay, A., 2006. Organic chemicals in sewage sludges. The Science of the Total Environment 367(2-3): 481-497.

Hernandez, T., Moreno, J.I., Costa, F., 1991. Influence of sewage sludge application on crop yields and heavy metal availability. Journal of Soil Science and Plant Nutrition 37(2): 201-210.

Hesselsøe, M., Jensen, D., Skals, K., Olesen, T., Møldrup, P., Roslev, P., Mortensen, G. K., Henriksen, K., 2001. Degradation of 4-nonylphenol in homogeneous and nonhomogeneous mixtures of soil and sewage sludge. Environmental Science \& Technology 35(18): 3695-3700.

Hu, M., Yuan, J., 2012. Heavy metal speciation of sewage sludge and its phytotoxic effects on the germination of three plant species. Advances Mathematical Research 347-353: 1022-1030.

Hue, N.V., Ranjith, S.A., 1994. Sewage sludges in Hawaii: chemical composition and reactions with soils and plants. Water, Air, and Soil Pollution 72(1-4): 265-283.

Kandeler, E., Tscherko, D., Bruce, K.D., Stemmer, M., Hobbs, P.J., Bardgett, R.D., Amelung, W., 2000. Structure and function of the soil microbial community in microhabitats of a heavy metal polluted soil. Biology and Fertility of Soils 32(5): 390-400.

Kang, J., Amoozegar, A., Hesterberg, D., Osmond, D.L., 2011. Phosphorus leaching in a sandy soil as affected by organic and inorganic fertlizer sources. Geoderma 161(3-4):194-201.

Kasatikov, V.A., Shabardina, N.P., Raskatov, V.A., 2017. After effect of the systematic application of urban sewage sludge on the agrobiological and ecological properties of soddy-podzolic soil. Plodorodie 1 (94): 43-46 [in Russian].

Kayikcioglu, H.H., Delibacak, S, 2018. Response of soil and plants health to sludge applied under Mediterranean biodegradation conditions. Applied Ecology and Environmental Research 16(4): 4893-4917.

Kizilkaya, R., Bayrakli, B., 2005. Effects of N-enriched sewage sludge on soil enzyme activities. Applied Soil Ecology 30(3): 192-202.

Kladivko, E.J., Nelson, D.W., 1979. Changes in soil properties from application of anaerobic sludge. Journal (Water Pollution Control Federation) 51(2): 325-332.

Kobasić,V.H., Picer, M., Picer, N., Calic, V., 2008. Transport of PCBs with Leachate Water from the Contaminated Soil. Bulletin of Environmental Contamination and Toxicology. 81(2):113-5

Kominko, H., Gorazda, K., Wzorek, Z., 2017. The possibility of organo-mineral fertilizer production from sewage sludge. Waste Biomass Valoriz., 1-11.

Korboulewsky, N., Dupouyet, S., Bonin, G., 2002. Environmental risks of applying sewage sludge compost to vineyards: carbon, heavy metals, nitrogen, and phosphorous accumulation. J. Environ. Qual. 31, 1522-1527.

Kulling, D., Stadelmann, F., Herter, U., 2001. Sewage Sludge - Fertilizer or Waste? UKWIR Conference, Brussels.

La Guardia, M.J., Hale, R.C., Harvey, E., Matteson Mainor, T., 2001. Alkylphenol ethoxylate degradation products in landapplied sewage sludge (biosolids). Environmental Science and Technology 35(24): 4798-4804. 
Langenkamp H., Part, H., Erhardt, W., Prüeß, A., 2001. Organic contaminants in sewage sludge for agricultural use. Joint Research Centre, Institute for Environment and Sustainability, Soil and Waste Unit, European Commission.

Logan, T.J., Harrison, B.J., 1995. Physical characteristics of alkaline stabilized sewage sludge (N-vitro soil) and their effects on soil properties. Journal of Environmental Quality 24(1): 153-164.

Lopez-Mosquera, M.E., Moiron, C., Carral, E., 2000. Use of dairy industry sludge as fertilizer for grassland in northwest Spain: heavy metal levels in the soil and plants. Resources, Conservation and Recycling 30(2): 95-109.

Maiti, P.S., Sah, K.D., Gupta, S.K., Banerjee, S.K., 1992. Evaluation of sewage sludge as a source of irrigation and manure. Journal of the Indian Society of Soil Science 40(1): 168-172.

Man, Y.B., Chow, K.L.,Cheng, Z., Mo, W.Y.,Chan, Y.H.,Lam, J.C.W., Lau, F.T.K., Fung, W.C., Wong, M.H., 2016. Profiles and removal efficiency of polycyclic aromatic hydrocarbonsbytwodifferent types ofsewagetreatmentplants in HongKong. Journal of Environmental Sciences 53: 196-206.

Mantis, I., Voutsa, D., Samara, C., 2005. Assessment of the environmental hazard from municipal and industrial waste water treatment sludge by employing chemical and biological methods. Ecotoxicology and Environmental Safety 62(3): 397-407.

Martinez, F., Cuevas, C., Teresa, W., Iglesias I., 2002. Urban organic wastes effects on soil chemical properties in degraded semiarid ecosystem. ${ }^{17}$ th World Congress of Soil Science (WCSS). 14-21 August 2002. Bangkok, Thailand. Symposium No. 20, pp. 1-9.

McBride, M.B., 1995. Toxic metal accumulation from agricultural use of sludge: are USEPA regulations prospective?. Journal of Environmental Quality 24(1): 5-18.

McLachlan, M.S., Horstmann, M., Hinkel, M., 1996. Polychlorinated dibenzo-p-dioxins and dibenzofurans in sewage sludge: sources and fate following sludge application to land. Science of The Total Environment 185(1-3): 109123.

Morera, M.T., Echeverria, J., Garrido, J., 2002. Bioavailability of heavy metals in soils amended with sewage sludge. Canadian Journal of Soil Science 82(4): 433-438.

Müller, J., Böhmer, W., Litz, N.T., 2006. Occurrence of polycyclic musks in sewage sludge and their behaviour in soils and plants-Part 1: behaviour of polycyclic musks in sewage sludge of different treatment plants in summer and winter. Journal of Soils and Sediments 6(4): 231-235.

Nandakumar, K., Ramamurthy, S., Rajarajan, A., Savarimuthu, E., 1998. Suitability of Dindigul town's sewage sludge for field application: nutritional perspective. Pollution Research 17(1): 61-63.

Nielson, G.H., Hogue, E.J., Nielson, D., Zebarth, B.J., 1998. Evaluation of organic wastes as soil amendments for cultivation of carrot and chard on irrigated sandy soils. Canadian Journal of Soil Science 78, 217-225.

Ojeda, G., Alcaniz, J.M., Ortiz, O., 2003. Runoff and losses by erosion in soils amended with sewage sludge. Land Degradation \& Development 14(6): 563-573.

Oleszczuk, P., 2006a. Characterization of Polish sewage sludges with respect to fertility and suitability for land application. Journal of Environmental Science and Health, Part A 41(7): 1119-1217.

Oleszczuk, P., 2006b. Persistence of polycyclic aromatic hydrocarbons (PAHs) in sewage sludge-amended soil. Chemosphere 65(9): 1616-1626.

Oleszczuk, P., Malara, A., Jośko, I., Lesiuk, A., 2012. The phytotoxicity changes of sewage sludge-amended soils. Water, Air, and Soil Pollution 223(8): 4937-4948.

Ozcan, S., Tor, A., Aydin, M. E., 2013. Investigation on the levels of heavy metals, polycyclic aromatic hydrocarbons, and polychlorinated biphenyls in sewage sludge samples and ecotoxicological testing. CLEAN Soil Air Water 41(4): 411-418.

Pappu, A., Saxena, M., Asolekar, S.R., 2007. Solid wastes generation in India and their recycling potential in building materials. Building and Environment 42(6): 2311-2320.

Parkpain, P., Sirisukhodom, S., Carbonell-Barrachina, A.A., 1998. Heavy metals and nutrients chemistry in sewage sludge amended Thai soils. Journal of Environmental Science and Health, Part A 33(4): 573-597.

Pascual, M., Hugas, M., Badiola, J.I., Monfort, J.M., Garriga, M., 1999. Lactobacillus salivarius CTC2197 Prevents Salmonella enteritidis colonization in chickens. Applied and Environmental Microbiology 65(11): 4981-4986.

Poluszyńska, J., Jarosz-Krzemińska, E., Helios-Rybicka, E., 2017. Studying the effects of two various methods of composting on the degradation levels of polycyclic aromatic hydrocarbons (PAHs) in sewage sludge. Water, Air, and Soil Pollution 228: 305.

Ramírez, W.A., Domene, X., Andrés, P., Alcañiz, J.M., 2008a. Phytotoxic effects of sewage sludge extracts on the germination of three plant species. Ecotoxicology 17(8): 834-844.

Ramírez,W. A., Domene, X., Ortiz, O., Alcañiz, J.M., 2008b. Toxic effects of digested, composted and thermally-dried sewage sludge on three plants. Bioresource Technology 99(15): 7168-7175.

Ramulu, U.S. Sree, 2002. Reuse of municipal sewage and sludge in agriculture. Scientific Publishers, Jodhpur, India.

Reynolds, E.R., 2018. Shortened lifespan and other age-related defects in bang-sensitive mutants of Drosophila melanogaster. G3: Genes, Genomes, Genetics 8(12): 3953-3960.

Rosińska, A., Dąbrowska, L., 2014. Sewage sludge digestion at increased micropollutant content. Chemical Engineering Research and Design 92(4): 752-757.

Rowell, D.M., Prescott, C.E., Preston, C.M., 2001. Decomposition and nitrogen mineralization from biosolids and other organic materials: relationship with initial chemistry. Journal of Environmental Quality 30(4): 1401-1410. 
Sanchez Monedero, M.A., Mondini, C., De Nobili, M., Leita, L., Roig, A., 2004. Land applications of biosolids. Soil response to different stabilization degree or treated organic matter. Waste Management 24(4): 325-332.

Sanitary and epidemiological rules 2.1.7.573-96 (SanPiN 2.1.7.573-96), "Hygienic requirements for the use of wastewater and its precipitation for irrigation and fertilizer" [in Russian].

Sanitary and epidemiological rules GN 2.1.7.2041-06 (SanPiN GN 2.1.7.2041-06) [in Russian].

Schröder, J.J., Cordell, D., Smit, A.L., Rosemarin, A., 2011. Sustainable Use of Phosphorus, EU Tender ENV.B.1/ETU/2009/0025, Wagenigen UR Report 357.

Singh, R.P., Agrawal, M., 2008. Potential Benefits and Risks of Land Application of Sewage Sludge. Waste Management 28(2): 347-358.

Singh, R.P., Sharma, B., Sarkar, A., Sengupta, C., Singh, P., Ibrahim, M.H., 2014. Biological responses of agricultural soils to fly ash amendments. In: Reviews of Environmental Contamination and Toxicology. Whitacre, D.M. (Ed.). Vol. 232, Springer International Publishing, Switzerland, pp. 45-60.

Smith, S. R., 2009. Organic contaminants in sewage sludge (biosolids) and their significance for agricultural recycling. Philosophical Transactions of The Royal Society A 367: 4005-4041.

Soclo, H. H., Garrigues, P.H., Ewald, M., 2000. Origin of polycyclic aromatic hydrocarbons (PAHs) in coastal marine sediments: Case studies in Cotonou (Benin) and Aquitaine (France) Areas. Marine Pollution Bulletin 40(5): 387396.

Sommers, L.E., 1977. Chemical composition of sewage sludges and analysis of their potential use as fertilizers. Journal of Environmental Quality 6(2): 225-232.

Sommers, L.E., Nelson, D.W., Yost, K.J., 1976. Variable nature of chemical composition of sewage sludges. Journal of Environmental Quality 5(3): 303-306.

Soon, Y.K., 1981. Solubility and sorption of cadmium in soils amended with sewage sludge. J. Soil Sci. 32, 85-95.

State All-Union Regulations R 17.4.3.07-2001 (GOST R standards 17.4.3.07-2001) "Requirements for the composition and properties of sewage sludge when used as fertilizers" [in Russian].

Suchkova, N., Darakas, E., Ganoulis, J., 2010. Phytoremediation as a prospective method for rehabilitation of areascontaminated by long-term sewage sludge storage: a Ukrainian-Greek case study. Ecological Engineering 36(4): 373-378.

Terry, R.E., Nelson, D.W., Sommers, L.E., 1979. Decomposition of anaerobically digested sewage sludge as affected by soil environmental conditions. Journal of Environmental Quality 8(3):342-347.

Tsadilas, C.D., Matsi, T., Barbayiannis, N., Dimoyiannis, D., 1995. Influence of sewage sludge application on soil properties and on the distribution and availability of heavy metal fractions. Communications in Soil Science and Plant Analysis 26(15-16): 2603-2619.

Urbaniak, M., Wyrwicka, A., Serwecińska, L., Zieliński, M., Tołoczko, W., 2014 Impact of sludge originated PCDDs/PCDFs on soil contamination and Salix sp. metabolism. 14th International Multidisciplinary Scientific Geoconference and EXPO. SGEM 2014. 17-26 June 2014, Albena, Bulgaria. 2(3): 169-174

USEPA, 1994. Guide to Septage Treatment and Disposal. EPA/625/R-94/ 002. Office of Research and Development, Washington, DC.

USEPA, 1999a. Control of pathogens and vector attraction in sewage sludge. United States Environmental Protection Agency (USEPA). Washington D.C.

USEPA, 1999b. Phytoremediation resource guide. Washington: U.S. Environmental Protection Agency, EPA, 542-B-99003.

Walter, I., Cuevas, G., Garcia, S., Martinez, F., 2000. Biosolid effects on soil and native plants production in a degraded semiarid ecosystem in central Spain. Waste Management and Research 18(3): 259-263.

Wang, P., Qu, E., Li, Z., Shuman, L.M., 1997. Fractions and availability of nickel in loessial soil amended with sewage or sewage sludge. Journal of Environmntal Quality 26(3): 795-801.

Wong, J.W.C., Li, K., Su, M., Fang, D.C., 2001. Toxicity evaluation of sewage sludge in Hong Kong. Environmental International 27(5): 373-380.

Wong, J.W.C., 1995. The production of artificial soil mix from coal fly ash and sewage sludge. Environmental Technology 16(8): 741-751.

Wyrwicka A, Steffani S, Urbaniak M. 2014. The effect of PCB-contaminated sewage sludge and sediment on metabolism of cucumber plants (Cucumis sativus L.). Ecohydrology \& Hydrobiology 14(1): 75-82.

Yunker, M.B., Macdonald, R.W., Vingarzan, R., Mitchell, R.H., 2002. PAHs in the Fraser river basin: A critical appraisal of PAH ratios as indicators of PAH source and composition. Organic Geochemistry 33(4): 489-515.

Zhai, J., Tian, W. Liu, K., 2011. Quantitative assessment of polycyclic aromatic hydrocarbons in sewage sludge from wastewater treatment plants in Qingdao, China. Environmental Monitoring and Assessment 180(1-4): 303-311.

Zhang, H., Xu, L., Zhang, Y., Jiang, M., 2014. The transformation of PAHs in the sewage sludge incineration treatment. Frontiers of Environmental Science \& Engineering 10(2): 336-340.

Zhang, P., Ge, L., Zhou, C., Yao, Z., 2011. Evaluating the performances of accelerated-solvent extraction, microwaveassisted extraction, and ultrasonic-assisted extraction for determining PCBs, HCHs and DDTs in sediments. Chinese Journal of Oceanology and Limnology 29(5): 1103-1112.

Zhidong, Li., Wenjing, Li., 2009. Technological parameters of exceed sludge anaerobic digestion in industrial waste water treatment plant. The Electronic Journal of Geotechnical Engineering Vol.14. 